\title{
Maturation of Circulatory Responses to Methionine-Enkephalin
}

\author{
EDMUND F. LAGAMMA, ${ }^{(48)}$ JOSEPH ITSKOVITZ, AND ABRAHAM M. RUDOLPH \\ Cardiovascular Research Institute and the Departments of Pediatrics, Physiology, and Obstetrics, Gynecology and \\ Reproductive Sciences, University of California, San Francisco, California, USA
}

\begin{abstract}
Summary
The cardiovascular and respiratory effects of the naturally occurring endogenous opiate, methionine-enkephalin, were studied in 23 fetal sheep, five newborn lambs, 15 pregnant sheep, and four nonpregnant ewes. The opiate peptide produced dose-dependent decreases in heart rate and blood pressure in fetal and neonatal lambs but increased heart rate and blood pressure followed immediately by decreased heart rate and blood pressure in pregnant ewes. The circulatory responses were examined by pharmacologic blockade of receptor activity and by vagotomy. The bradycardia and hypotension in the fetus and tachycardia and hypertension in the adult were shown to be mediated by autonomic efferent nerves. Sinoaortic denervation did not affect the fetal responses to infused enkephalin. Respiration decreased in fetal as well as postnatal animals even at doses of methionine-enkephalin that did not significantly affect heart rate and blood pressure. These data indicate that the cardiovascular effects of infused enkephalins undergo maturational changes and are mediated by the autonomic nervous system.
\end{abstract}

Endorphins and enkephalins are widely distributed throughout the brain, spinal cord, and peripheral autonomic nervous system $(13,37)$. Opioid receptors are located in these same areas, but are particularly abundant in regions associated with pain perception and pituitary hormone release $(10,34,35)$ and in the medullary nuclei concerned with cardiopulmonary regulation $(10,14,34,35)$. Opiate receptors also increase both in number and in affinity during the latter third of gestation and in the first few weeks after birth in rats $(8,9,33)$. Because endogenous opiates, such as enkephalin, can modify cardiovascular and pulmonary function in adults $(2,5,25,36)$, we wished to assess whether there were developmental changes in circulatory regulation by endogenous opiates.

To do this, we chose methionine-enkephalin as an opiate receptor agonist because it has been detected in high concentrations in the adrenal medulla $(17,44)$, is secreted into the circulation after appropriate stimulation $(16,39,41)$, and is found widely distributed in autonomic ganglia $(19,30,37)$. In addition, because it is known that the autonomic nervous system matures postnatally ( 1 , 3,28 ), and that the enkephalins may function as cotransmitters with acetylcholine and catecholamines in autonomic ganglia and the adrenal medulla $(18,41)$, it is possible that maturational changes in the enkephalinergic system occur and may be important in modifying the cardiovascular response to stress.

\section{MATERIALS AND METHODS}

Surgery. Surgery was performed in 25 time-dated pregnant ewes at 120-130 days gestation (term is $145 \pm 5$ days). Lower body anesthesia was accomplished by epidural injection of $2 \%$ tetracaine hydrochloride (Winthrop Laboratories, CA). The uterus was exposed through a midline incision and fetal hind limbs were delivered through a small hysterotomy. Polyvinyl catheters were inserted into both pedal arteries and veins and advanced to the descending aorta and inferior vena cava, respectively. The fetal catheters were exteriorized at the flank of the ewe and stored in a cloth pouch sewn to the skin. Silver electrodes were sewn subcutaneously on the fetal chest and were used to monitor the fetal electrocardiogram. A tracheal catheter was inserted in most fetuses to monitor fetal intrauterine respiratory movements. Catheters were also inserted into a maternal artery and vein at the time of surgery. Three newborn lambs and four nonpregnant ewes had arterial and venous catheters placed under local anesthesia with $1 \%$ lidocaine hydrochloride (Cutter Laboratories, Berkeley, CA). Fetuses and ewes were studied from 1-7 days, and neonatal lambs from 1 day through 4 wk after surgery. Arterial $\mathrm{pH}, \mathrm{PCO}_{2}, \mathrm{PO}_{2}$ and hemoglobin were normal in all animals at the time of study and were determined on a Radiometer Blood Gas Analyzer (Copenhagen, Denmark). Heart rate was recorded continuously with a Beckman 8-channel recorder (Schiller Park, IL) and was derived from the aortic pressure signal recorded from a Statham P23Db pressure transducer (Oxnard, CA). Mean aortic pressure was derived from electrical damping of the phasic pressure tracing and recorded simultaneously on a separate channel.

Protocol. After a suitable baseline recording of heart rate and blood pressure was obtained ( $\geq 3 \mathrm{~min}$, e.g., last $30 \mathrm{sec}$ illustrated in Fig. 1), uniform doses of methionine-enkephalin (Sigma Chemical Co., St. Louis, MO) were injected into both fetuses (weight, 2-3 kg, and 120-130 days gestation) and newborn lambs (weight, $5-8 \mathrm{~kg}$ and age, $2-4 \mathrm{wk})$ in various amounts $(0.3,3,5,10,15,30$, and $300 \mathrm{nmole}$, in random order; range, $0.1-150 \mathrm{nmole} / \mathrm{kg}$ ). To study adult female animals (weight, $45-55 \mathrm{~kg}$ ) a dose of 3000 nmole (range, $55-65 \mathrm{nmole} / \mathrm{kg}$ ) was given because it was apparent after initial experiments that lower amounts did not affect the variables measured and that the weight-specific dose range was narrow. Later, when examining mechanisms at various ages, we gave a single, weight-specific dose chosen to produce an obvious and significant cardiovascular response, but a response of short duration ( $\leq 1 \mathrm{~min})$. This was accomplished with a dose of approximately $15 \mathrm{nmole} / \mathrm{kg}$ ( 30 nmole) in fetal and neonatal animals and with a dose of approximately 50 nmole $/ \mathrm{kg}$ in adult animals. In adult animals, a dose of $3000 \mathrm{nM}$ was given because the lower amounts did not affect the variables measured. The peptide was dissolved in $1 \mathrm{ml}$ of $0.9 \% \mathrm{NaCl}$ solution and administered through the venous catheter. Heart rate and blood pressure were allowed to return to control values for 3-5 min before a second dose was given. The mechanism of the fetal heart rate response studied by selective pharmacologic blockade of muscarinic receptors [atropine (Elkins-Sinn, Inc., Cherry Hill, NJ), $0.2 \mathrm{mg} / \mathrm{kg}$ (1)], nicotinic receptors [trimethaphan (Roche Laboratories, Nutley, NJ), 150 $\mu \mathrm{g} / \mathrm{kg} / \mathrm{min}(1)]$, and opiate receptors (naloxone, $\mathrm{HCl}$, gift Endo Labs, Garden City, NY). In addition bilateral cervical vagotomy and sinoaortic denervation [Itskovitz, J. and Rudolph, A.M.: Sinoaortic denervation in fetal sheep, Am. J. Physiol., 242: H916 (1982)] was performed in five fetuses.

The mechanism of the heart rate and blood pressure responses to methionine-enkephalin in the ewe was also examined by preferential pharmacologic blockade of autonomic receptors. Specifically, muscarinic receptors were blocked with atropine $(15-20 \mathrm{mg}$, 

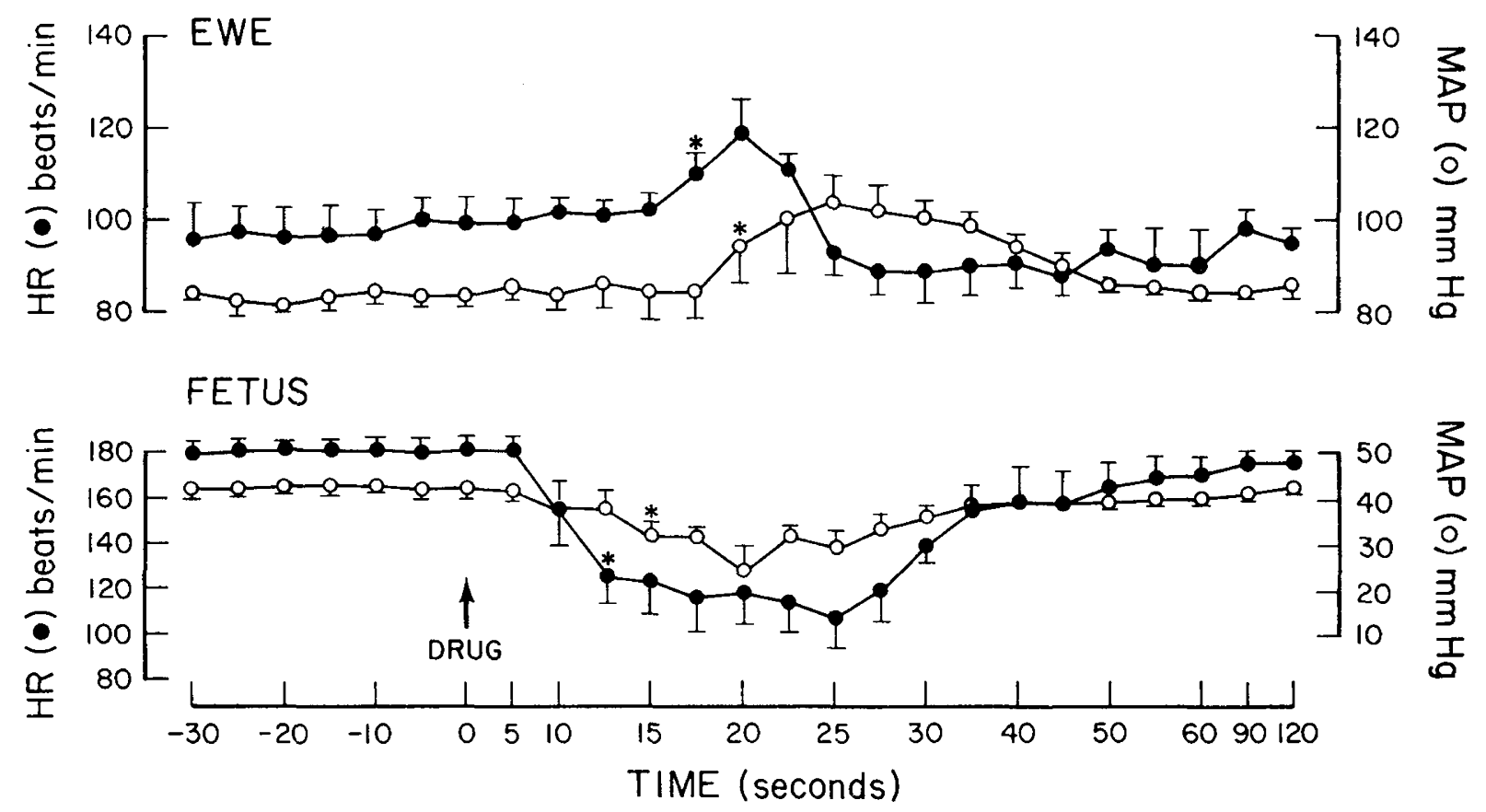

Fig. 1. Methionine-enkephalin causes opposite effects on heart rate and mean aortic blood pressure in the fetus at 0.8 gestation $(n=5)$ when compared to the pregnant adult $(\mathrm{n}=5)$. Asterisks indicate the first heart rate or blood pressure values different from control by Scheffe's multiple contrasts test $(\overline{\mathrm{x}} \pm \mathrm{S}$.E., $P<0.05)$.

IV) and propranolol (Ayerst Laboratories, New York, NY, $10 \mathrm{mg}$, IV) was used to block beta-adrenergic receptors. Alpha-adrenergic receptor blockade was accomplished with either phenoxybenzamine (Smith, Kline, and French, Philadelphia, PA, $1 \mathrm{mg} / \mathrm{kg}$, IV) or phentolamine (Ciba Pharmaceutical Co., Summit, NJ, $10 \mathrm{mg}$, IV). Two alpha-adrenergic receptor antagonists were used in an attempt to test for and limit the possible interaction between the opiate system and central alpha $\mathrm{a}_{2}$ receptor regulation of the circulation $(11,24)$. Phenoxybenzamine and phentolamine were chosen because they block both presynaptic $\left(\right.$ alpha $\left._{1}\right)$ and postsynaptic (alpha ${ }_{2}$ ) receptors by independent and unequal mechanisms (42). They also have unequal effects at these receptors and on central regulation of brainstem reflexes $(22,42)$. Thus, if we could eliminate the vasopressor response to $200 \mu \mathrm{g}$ of intravenous phenyleph-

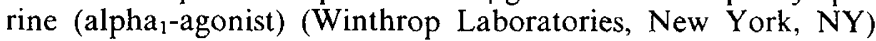
and thereby demonstrate equivalence peripherally, any differences that occurred would suggest central alpha:-opiate receptor interactions, which could override the weaker alpha ${ }_{2}$ antagonist effects of these drugs. Effective beta-adrenergic receptor blockade was demonstrated by the lack of a heart rate response to isoproterenol (Elkins-Sinn, Inc., Cherry Hill, NJ, $0.05 \mu \mathrm{g} / \mathrm{kg}$, IV).

Statistical methods. Continuous data were tabulated from instantaneous values of heart rate and mean aortic blood pressure and were analyzed statistically by one-way analysis of variance with repeated measures. If the analysis of variance indicated a significant event had occurred, the Scheffé multiple contrast test was employed to compare the mean values of the sequentially tabulated variables (at the designated times after injection, e.g., Fig. 1), to the baseline period recordings taken as one group. The Scheffé test is an a priori statistical procedure that is uniquely suited for grouping baseline data in this way (45). The Scheffé test also provides the greatest strength in analyzing continuous data after an analysis of variance procedure demonstrates a significant event has occurred because it is less likely than other similar tests to falsely identify a difference that does not exist (45).

\section{RESULTS}

Methionine-enkephalin, in doses of $3 \mathrm{nM}$ reduced fetal heart rate in most animals but a statistically significant reduction in heart rate and blood pressure was achieved only at doses greater than $10 \mathrm{nM}$. There was a dose response relationship between fetal heart rate and methionine-enkephalin with the maximal decrease of heart rate (56\% reduction from control) occurring at the 300 $\mathrm{nM}$ (approximately $150 \mathrm{nM} / \mathrm{kg})$ dose $(179 \pm 4$ S.E. bpm to $79 \pm$ 5 S.E. bpm $n=4, P<0.01$, Scheffé's test) lasting for 10-15 sec (Table 1). There was also a dose-dependent relationship with mean arterial pressure, which fell $31 \%$ after $300 \mathrm{nM}$ of methionineenkephalin $(42.7 \pm 2.3 \mathrm{~S}$.E. $\mathrm{mmHg}$ to $24.8 \pm 6.1$ S.E. $\mathrm{mmHg}, n$ $=4, P<0.05$, Scheffé's test). The blood pressure reduction followed the decrease in fetal heart rate and both heart rate and blood pressure returned to control values within $1 \mathrm{~min}$ after administration of the peptide at all doses used (Fig. 1). Repeat doses of methionine-enkephalin given within $10 \mathrm{sec}$ of the peak heart rate response (e.g., at $25-35 \mathrm{sec}$ after initial dose) showed tachyphylaxis and caused no further change in fetal heart rate or pressure; however, repeat doses after this period but before full recovery usually produced an additional and equivalent heart rate response. No changes in electrical conduction in the heart were noted on the electrocardiogram after the infusion of the drug. This indicated that the bradycardia was sinus in origin (Fig. 2).

The average peak reduction in fetal heart rate at the $30 \mathrm{nM}$ dose of methionine-enkephalin (approximately $15 \mathrm{nM} / \mathrm{kg}$ ) was $47 \%$ ( $n=5, P<0.002$, Scheffe's test, Fig. 1 and Table 1). This dose was used in subsequent studies to test the mechanism of the fetal bradycardia. Newborn lambs $(n=5)$, studied serially up to $4 \mathrm{wk}$ after birth, showed similar directional changes in heart rate and blood pressure as the fetus.

Adult sheep did not respond until a dose of $3000 \mathrm{nM}$ of methionine-enkephalin was given. No other doses between 300 $\mathrm{nM}(6 \mathrm{nM} / \mathrm{kg})$ and $3000 \mathrm{nM}(60 \mathrm{nM} / \mathrm{kg})$ were used. In contrast to the fetal and newborn lambs (Table 2), in pregnant ewes there was an initial increase in heart rate $(98 \pm 6 \mathrm{~S}$.E. bpm, to $119 \pm 7$ S.E. bpm, $n=5, P<0.001$, Scheffé's test) and mean arterial blood pressure $(83.4 \pm 2.5 \mathrm{~S}$.E. $\pm \mathrm{mmHg}$, to $103.2 \pm 5.9$ S.E. $\mathrm{mmHg}, n$ $=5, \mathrm{P}<0.001$, Scheffé's test) followed by bradycardia and hypotension (Fig. 1). Both the heart rate and blood pressure responses returned to control levels by $1 \mathrm{~min}$ after the injection. Although vascular reactivity to other nonopiate vasoactive peptides differs between pregnant and nonpregnant animals (43), we did not observe any difference in blood pressure response to methionine-enkephalin in pregnant and nonpregnant ewes (Table 2 ), but in the nonpregnant animals the heart rate did not increase significantly (Table 2). 
Table 1. Dose response relationship of peak cardiovascular effects of methionine-enkephalin in fetal lambs

\begin{tabular}{|c|c|c|c|c|c|}
\hline \multirow{2}{*}{$\begin{array}{l}\text { Dose } \\
\text { (nmole) }\end{array}$} & \multirow[b]{2}{*}{$n$} & \multicolumn{2}{|c|}{ Fetal heart rate (BPM) } & \multicolumn{2}{|c|}{$\begin{array}{l}\text { Mean aortic blood pressure } \\
\qquad(\mathrm{mmHg})\end{array}$} \\
\hline & & Baseline & Effect & Baseline & Effect \\
\hline 0.3 & 2 & \multicolumn{2}{|c|}{ No response } & \multicolumn{2}{|c|}{ No response } \\
\hline 3.0 & 5 & $178 \pm 4$ & $174 \pm 5$ & $42.5 \pm 1.1$ & $42.7 \pm 1.2$ \\
\hline 15 & 5 & $185 \pm 4$ & $131 \pm 19^{*}$ & $46.0 \pm 2.1$ & $32.4 \pm 7.7$ \\
\hline 30 & 5 & $174 \pm 5$ & $106 \pm 14 \ddagger$ & $42.1 \pm 1.5$ & $29.4 \pm 3.7 \neq$ \\
\hline 300 & 4 & $179 \pm 4$ & $79 \pm 5 \dagger$ & $42.7 \pm 2.3$ & $24.8 \pm 6.1^{*}$ \\
\hline
\end{tabular}

$* P<0.05, \dagger P<0.01, \ddagger P<0.002$, mean \pm S.E.

In pregnant ewes given $3000 \mathrm{nM}$ of methionine-enkephalin, fetuses did not show responses in heart rate or blood pressure. Also, no cardiovascular responses were noted in the twin fetus when its mate received up to $300 \mathrm{nM}$ of methionine-enkephalin. Enkephalins either do not cross the placental barrier or are rapidly catabolized by the placenta. The mechanism of the fetal bradycardia was tested using a $30 \mathrm{nM}$ dose of methionine-enkephalin before and after pharmacologic blockade in 15 animals studied separately. The heart rate response was effectively blocked by atropine, trimethaphan, and vagotomy (Fig. 3); however, naloxone in doses of $1 \mathrm{mg} / \mathrm{kg}$ diminished the heart rate and blood pressure responses to methionine-enkephalin (Fig. 2), but a dose of $3 \mathrm{mg} /$ $\mathrm{kg}$ was needed to abolish them $(n=4)$. Sinoaortic denervation did not alter the heart rate or blood pressure responses $(n=5)$ (Table 2).
The mechanisms of the increased heart rate and blood pressure responses in the adult ewe were also examined by preferential pharmacologic blockade of autonomic receptors. The initial tachycardia was prevented by beta-adrenergic receptor blockade (propranolol) without affecting the pressor response $(n=4)$.

Data from alpha adrenergic receptor blockade with phenoxybenzamine $(n=3)$ or phentolamine $(n=3)$ were analyzed separately. Due to the small number of animals in each group, data from respective baseline periods were compared to the corresponding paired group of values obtained at the time of maximal response (e.g., from 12.5-27.5 sec as previously determined in untreated animals, Fig. 1). In ewes pretreated with phenoxybenzamine, methionine-enkephalin decreased heart rate from $122 \pm$ 18 S.E. bpm to $95 \pm 19$ S.E. bpm $(P<0.001$, Scheffé's test $)$ and decreased mean aortic pressure from $77.9 \pm 3.3 \mathrm{~S}$.E. $\mathrm{mmHg}$ to $69.2 \pm 6.4$ S.E. $\mathrm{mmHg}$ (not significant). Phentolamine had a similar, effect decreasing heart rate from $187 \pm 4$ S.E. bpm to 152 \pm 27 S.E. bpm $(P<0.02)$ and decreasing mean aortic pressure from $103.7 \pm 4.3 \mathrm{~S}$.E. $\mathrm{mmHg}$ to $102.7 \pm 6.1 \mathrm{~S}$.E. $\mathrm{mmHg}$ (not significant). These changes in heart rate and blood pressure were abolished by atropine when examined in a single animal from each group.

In five fetuses, intrauterine respiratory movements were abolished immediately (less than $5 \mathrm{sec}$ ) after injection of methionineenkephalin in low doses that did not significantly affect heart rate or blood pressure (Fig. 4A). In contrast, $0.9 \% \mathrm{NaCl}$ solution had no consistent effects on respiration in these animals. Similarly, the depth and frequency of respiration immediately decreased or apnea occurred for up to $30 \mathrm{sec}$ after methionine-enkephalin in the three ewes and three lambs studied in a similar way (Fig. 4B).

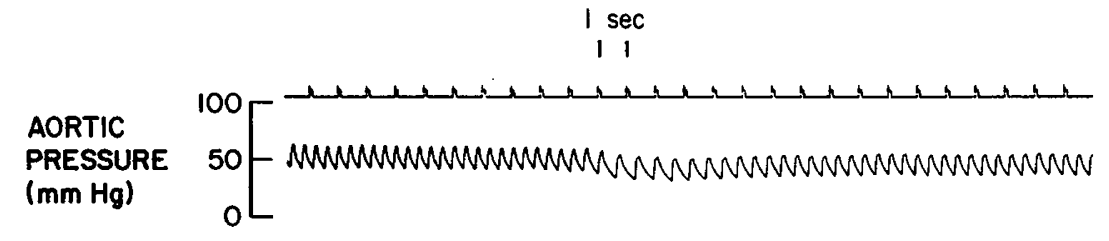

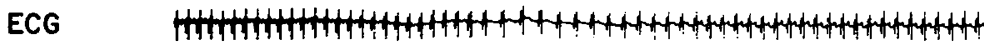

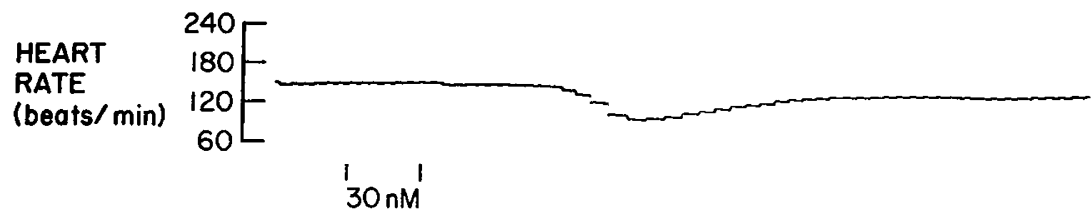

Fig. 2. Fetal mean aortic pressure, electrocardiogram, and heart rate response to $30 \mathrm{nM}$ methionine-enkephalin. Note there is no change in the electrocardiogram.

Table 2. Comparison of peak heart rate effects to methionine-enkephalin in perinatal and adult sheep ${ }^{1}$

\begin{tabular}{|c|c|c|c|c|c|}
\hline & Fetus & $\begin{array}{c}\text { Sinoaortic } \\
\text { denervated } \\
\text { fetuses }\end{array}$ & Lamb & \multicolumn{2}{|c|}{ Ewe } \\
\hline & $120-130$ day & $120-130$ day & $2-4 w k$ & Pregnant & Nonpregnant \\
\hline & $(n=5)$ & $(n=5)$ & $(n=5)$ & $(n=5)$ & $(n=4)$ \\
\hline \multicolumn{6}{|l|}{ Baseline } \\
\hline (HR) & $174 \pm 5$ & $181 \pm 12$ & $244 \pm 2$ & $98 \pm 6$ & $124 \pm 2$ \\
\hline (HR) & $106 \pm 14^{*}$ & $101 \pm 18 \dagger$ & $181 \pm 14 \ddagger$ & $119 \pm 7 \S$ & $128 \pm 5$ \\
\hline (MAP) & $29.4 \pm 3.7^{*}$ & $31.8 \pm 2.7 \ddagger$ & $58.8 \pm 6.6 \|$ & $103.2 \pm 5.9 \S$ & $122.5 \pm 4.8 \|$ \\
\hline Dose (nmole) & $15 / \mathrm{kg}$ & $15 / \mathrm{kg}$ & $15 / \mathrm{kg}$ & \multicolumn{2}{|c|}{$55 / \mathrm{kg}$} \\
\hline
\end{tabular}

${ }^{1} \mathrm{HR}$, heart rate and MAP, mean aterial pressure.

$\| P<0.05, \dagger P<0.02, \ddagger P<0.01,{ }^{*} P<0.002, \S P<0.001$.

$\overline{\mathrm{x}} \pm \mathrm{SEM}$. 


\section{DISCUSSION}

These data indicate that fetal and newborn lambs respond to methionine-enkephalin with bradycardia and resulting hypotension that is mediated by increased activity of vagal efferent nerves consistent with the suggested central site of action for leucineenkephalin, methionine-enkephalin $(2,5,25,36)$, and other nonpeptide opiate drugs $(26,27)$ in several species.

The increased heart rate and blood pressure that occurs in the ewe after methionine-enkephalin is similar to that reported when administered centrally or peripherally $(2,5,25,36)$; the effects can be modified or eliminated by autonomic receptor blockade. The responses in the sheep fetus are quite different in that bradycardia and hypotension are induced by methionine-enkephalin. The bradycardia is blocked by atropine, indicating it is vagally-mediated. Our studies indicate that the cardiovascular effects of infused methionine-enkephalin are mediated by the autonomic nervous system and that the effects develop to maturity in sheep older than $4 \mathrm{wk}$ of age. Animals of all ages responded with a decrease in respiratory frequency, suggesting that there is a difference in the developmental pattern in the pathways and receptors mediating the peptide's respiratory and cardiovascular effects.

It has been suggested that the opiate receptors, which mediate

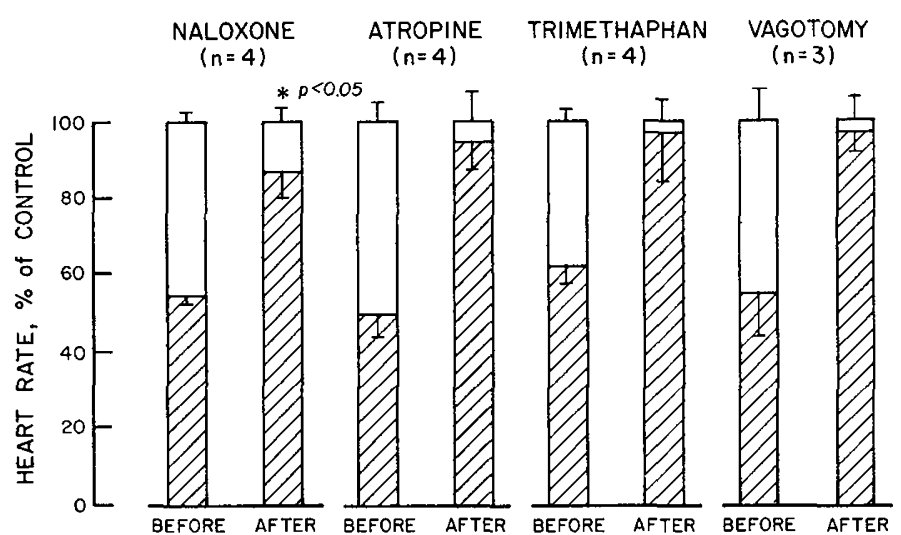

Fig. 3. Peak fetal heart rate responses as $\%$ of control following $30 \mathrm{nM}$ (15 $\mathrm{nM} / \mathrm{kg}$ ) of methionine-enkephalin (hatched areas) before and after selective pharmacologic blockade ( $\bar{x} \pm$ S.E.). Control heart rate was 176 \pm 3 S.D. $(n=15)$. Data were analyzed by paired $t$ test. All heart rate responses to methionine-enkephalin before manipulation were significantly different from control values $(P<0.002$, paired $t$ test). See text for details.

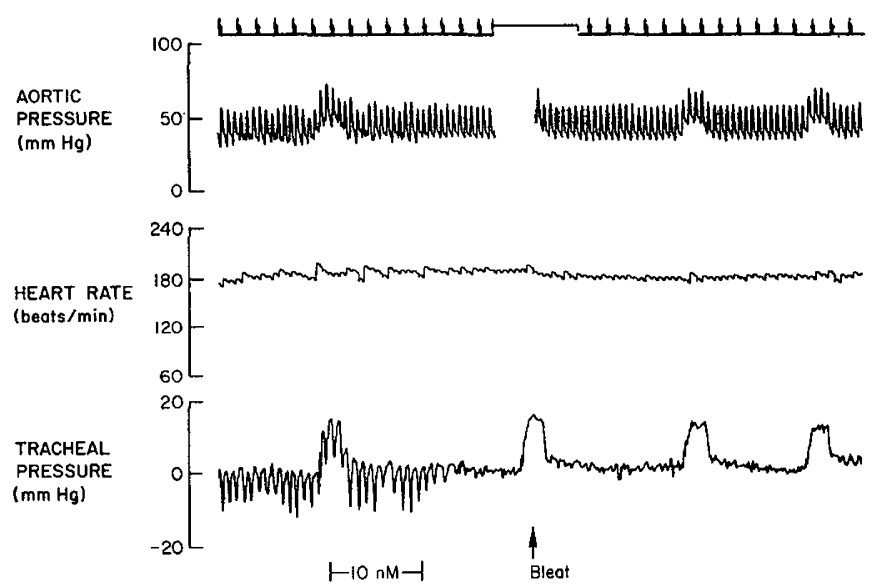

the analgesic and respiratory effects of opiates $(33,40)$, undergo developmental changes in number and affinity during the postnatal period $(8,9,10,46)$. Subpopulations of opiate receptors (e.g., mu, delta, kappa, sigma) $(27,29,31)$ may also show developmental changes but this possibility has yet to be examined. On the other hand, because methionine-enkephalin is estimated to be eight times more potent in delta opiate receptor assays than it is in mu receptor assays (29), it is thought to preferentially stimulate deltatype opiate receptors on an equimolar basis. It would be appealing to suggest that the maturational effects we now describe are due to deficiencies in fetal delta opiate receptors because preferential $\mathrm{mu}$ receptor stimulation (with morphine) produces bradycardia and hypotension (31). This hypothesis will require further proof.

Alternatively, the difference between the perinatal and adult responses to methionine-enkephalin may be attributed to the maturation of the blood-brain barrier in the perinatal period. This is unlikely for several reasons. In the sheep, the blood-brain barrier is effectively present by 125 days gestation (6). In adults animals, it is absent in the region of the area postrema (7) where endogenous opiate receptors $(10,14,34,35)$ and the autonomic nuclei of the brainstem are located. The barrier is also absent in parts of the hypothalamus (7). Because the brainstem (area postrema) and hypothalamus are both involved with central autonomic circulatory controls, they are important as potential sites of action for circulating opiate peptides. For example, the region of the area postrema is thought to be the site of action for another circulating peptide, the octopeptide angiotensin II (12) (methionine-enkephalin is a pentapeptide). Finally, even if there were a blood-brain barrier present in the region where the opiates act, methionine-enkephalin has been shown to cross the blood-brain barrier in rats at rates fast enough (less than $5 \mathrm{sec}$ ) to account for a central cardiovascular effect (21).

Stimulation of the afferent limb of cardiovascular reflexes (e.g., baroreflex or chemoreflex) may also be the mechanism by which methionine-enkephalin acts in the fetus. The presence of a similar opiate effect on heart rate and blood pressure in sinoaortic denervated fetuses again implicates a central site of action for the infused peptides. We did not study other cardiovascular reflexes that can produce bradycardia and apnea when activated; therefore, we cannot eliminate stimulation of the Bezold-Jarisch reflex (coronary chemoreflex) or the pulmonary $J$ receptor reflex in explaining the fetal and neonatal lamb's response to methionine-enkephalin. On the other hand, the ewe's response to methionine-enkephalin is exactly opposite to both the expected response of the coronary chemoreflex to veratridine (1) and to chemostimulation of pulmonary $J$ receptors. Unless there are other causes for the

Fig. 4. (Left hand panel), recordings of mean aortic blood pressure, heart rate, and tracheal pressure in a fetal lamb (125 days gestation) that received $10 \mathrm{nM}$ of methionine-enkephalin during a period of respiratory activity. Note the prompt cessation of respiratory motion and the absence of a significant effect on fetal heart rate. Timing marks: one/sec, long mark indicates minute elapsed. (Right hand panel), recordings of mean aortic blood pressure, heart rate, and tracheal pressure in a fetus at 125 day gestation in a 2-wk-old lamb, and in a pregnant ewe. Respiratory excursions are displayed with heart rate and blood pressure. Note the distinct change in respiratory activity, independent of the timing of the circulatory effects, in response to methionine-enkephalin (fetus and lamb, 15 nanomole $/ \mathrm{kg}$; ewe 50 nanomole $/ \mathrm{kg}$ ). 
maturational effects we describe, it appears that the cardiovascular effects of intravenous methionine-enkephalin in sheep result from its direct action on central autonomic centers and not from receptor stimulation in peripheral cardiovascular reflexes.

The unexpected vagal bradycardia and hypotension after infusion of this peptide in ewes treated acutely with either phenoxybenzamine or phentolamine is intriguing. These results may simply indicate a sensitization to the hypotensive and bradycardic effects of opioid drugs due to an inability for compensatory vasoconstriction to occur under these conditions (42) or may be evidence of more subtle interactions in central autonomic centers. For example, central alpha ${ }_{2}$ receptor agonists produce bradycardia and hypotension $(4,42)$. Because we did not test for the effectiveness of the alpha $a_{2}$ antagonism achieved, our data may indicate that these peptides have alpha $a_{2}$ agonist activity $(11,24)$, which can override partial alpha 2 receptor antagonism; however, we did not observe these effects after any other manipulation, thus making this an unlikely possibility. Alternatively, it has been shown that phenoxybenzamine increases binding of $\left[{ }^{3} \mathrm{H}\right]$ morphine to central opiate receptors in vivo (38) and by this mechanism central alpha antagonists may actually enhance binding of methionine-enkephalin to these same receptors. In this fashion, methionine-enkephalin could conceivably become a preferential agonist at opiate receptors, which preferentially bind morphine and thereby cause bradycardia and hypotension as well.

Methionine-enkephalin is found in autonomic ganglia $(19,30$, $37)$, in the adrenal medulla $(17,44)$, and in brain stem nuclei concerned with cardiopulmonary regulation $(10,14,34,35)$. Our identification of maturational changes in the autonomic nervous system's response to methionine-enkephalin may be yet another important factor to consider in understanding the postnatal maturation of the autonomic nervous system $(1,3)$ as well as the pathophysiology of perinatal syndromes associated with autonomic nervous system imbalance, such as neonatal apnea (23). In support of this hypothesis, is evidence that naloxone can stimulate fetal and neonatal respiratory activity $(15,20,32)$ and our evidence that naloxone also antagonizes the circulatory effects of methionine-enkephalin.

\section{REFERENCES AND NOTES}

1. Assali, N. S., Brinkman, C. R., Woods, R., Jr., Dandavino, A., and Nuwayhid, $B$. Ontogenesis of the autonomic control of cardiovascular functions in the sheep: In: L. D. Longo and D. D. Reneau, Eds.: Fetal and Newborn Cardiovascular Physiology, vol. I; Developmental Aspects. pp. 47-91 (Garland STPM Press, New York, NY, 1978).

2. Bellet, M., Elghozi, J. L., Meyer, P., Pernollet, M. G., and Schmitt, H.: Central cardiovascular effects of narcotic analgesics and enkephalins in rats. $\mathrm{Br}$. $\mathrm{J}$. Pharmacol., 71: 365 (1980)

3. Black, I. B.: Regulation of autonomic development. Ann. Rev. Neurosci., 1: 183 (1978).

4. Blaschke, T. F. and Melmon, K. L.: Antihypertensive agents and the drug therapy of hypertension. In: The Pharmacological Basis of Therapeutics, 6th ed. pp. 793-799 (Macmillan Publishing Co., Inc., New York, NY, 1980).

5. Bolme, P., Fuxe, K., Agnati, L. F., Bradly, R., and Smythies, J.: Cardiovascular effects of morphine and opioid peptides following intra-cisternal administration in chloralose-anesthetized rats. Eur. J. Pharmacol., $48: 319$ (1978).

6. Bradbury, M.: The blood-brain barrier during the development of the individual and the evolution of the phylum. In: The Concept of the Blood-Brain Barrier. pp. 289-322 (John Wiley and Sons, New York, NY, 1979).

7. Bradbury, M.: Regional differences in blood-interstitial fluid exchange throughout the nervous system. In: The Concept of the Blood-Brain Barrier. pp. 116136 (John Wiley and Sons, New York, NY, 1979).

8. Clendeninn, N. J., Petraitis, M., and Simon, E. J.: Ontological development of opiate receptors in rodent brain. Brain. Res., 118: 157 (1976)

9. Coyle, J. T., and Pert, C. B.: Ontogenic development of $\left[{ }^{3} \mathrm{H}\right]$ naloxone binding in rat brain. Neuropharmacology, 15: 555 (1976).

10. Duka, T., Schubert, P., Wuster, M., Stoiber, R., and Herz, A.: A selective distribution pattern of different opiate receptors in certain areas of rat brain as revealed by in vitro autoradiography. Neurosci. Let., 21: 119 (1981).

11. Farsang, C., Ramirez-Gonzalex, M. D., Mucci, L., and Kunos, G.: Possible role of an endogenous opiate in the cardiovascular effects of central alpha adrenoceptor stimulation in spontaneously hypertensive rats. J. Pharmacol. Exp. Ther., 214: 203 (1980).

12. Ferrario, C. M., Gildenberg, P. L., and McCubbin, J. W.: Cardiovascular effects of angiotensin mediated by the central nervous system. Circ. Res., 30: 257 (1972).

13. Goldstein, A.: Opioid peptides (endorphins) in pituitary and brain. Science, 193: 1081 (1976).
14. Goodman, R. R., Snyder, S. H., Kuhar, M. J., and Young, W. S., III: Differentiation of delta and mu opiate receptor localizations by light microscopic autoradiography. Proc. Nat. Acad. Sci. U.S.A., 77: 6239 (1980).

15. Grunstein, M., Hazinski, T. A., Schlueter, M. A., and Tooley, W. H.: Effect of naloxone on the respiratory response to hypoxia in newborn rabbits. Pediatr Res., 14: 1304 (1980).

16. Hexum, T. D., Hanbauer, I., Yang, H.-Y. T., and Costa, E.: Secretion of enkephalin-like peptides from dog adrenal gland (Abstr.). Fed. Proc., 39: 1799 (1980).

17. Hexum, T. D., Yang, H.-Y. T., and Costa, E.: Biochemical characterization of enkephalin like immunoreactive peptides of adrenal glands. Life Sci., 27: 1211 (1980).

18. Hokfelt, T., Lundberg, J. M., Schultzberg, M., Johansson, O., Ljungdahl, A., and Rehfeld, J.: Coexistence of peptides and putative transmitters in neurons. In: E. Costa and M. Trabucchi, Eds: Neural Peptides and Neural Communication, Adv. Biochem. Psychopharm: 22, pp. 1-24 (Raven Press, New York, NY, 1980).

19. Hughes, J., Kosterlitz, H. W., and Smith, T. W.: The distribution of methionineenkephalin and leucine-enkephalin in the brain and peripheral tissues. Br. J. Pharmacol., 61: 639 (1977).

20. Isom, G. E. and Elshowihy, R.: Stimulation of respiration by naloxone in normal and stressed rats (Abstr.). Fed. Proc., 40: 282 (1981).

21. Kastin, A. J., Nissen, C., Schally, A. V., and Coy, D. H.: Blood-brain barrier, half-time disappearance and brain distribution for labeled enkephalin and a potent analog. Br. Res. Bull., 1: 583 (1976).

22. Kobinger, W. and Walland, A.: Facilitation of vagal reflex bradycardia by an action of cloridine on central alpha-receptors. Eur. J. Pharmacol., 19: 210 (1972).

23. Krauss, A. N.: Sudden infant death syndrome: In: E. M. Scarpelli, P.A.M. Auld, and H.S. Goldman, Eds.: Pulmonary Disease of the Fetus, Newborn and Child. pp. 522-523 (Lea and Febiger, Philadelphia, PA, 1978).

24. Kunos, G., Farsang, C., and Ramirez-Gonzales, M. D.: $\beta$-Endorphin: possible involvement in the antihypertensive effect of central alpha-receptor activation. Science, 211: 82 (1981)

25. Laubie, M., Schmitt, H., Vincent, M., and Remond, G.: Central cardiovascular effects of morphinomimetic peptides in dogs. Eur. J. Pharmacol., 46: 67 (1977).

26. Laubie, M. Schmitt, H. and Drouillat. M. Central sites and mechanisms of the hypotensive and bradycardic effects of the narcotic analgesic agent fentanyl. Naunyn-Schiedeberg, Arch. Pharmacol., 296: 255 (1977)

27. Laubie, M Schmitt, $\mathrm{H}$. Canellas, J., Roquebert J and Demichel, P. Centrally mediated bradycardia and hypotension induced by narcotic analgesics: Dextromoramide and Fentanyl. Eur. J. Pharmacol., 28: 66 (1974).

28. Lebowitz, E. A., Novick, J. S., and Rudolph, A. M.: Development myocardial sympathetic innervation in the fetal lamb. Pediatr. Res. 6.887 (1972)

29. Lord. J. A. H.. Waterfield. A. A.. Hughes, J., and Kosterlitz. H. W.: Endogenous opioid peptides: Multiple agonists and receptors. Nature, 267: 495 (1977).

30. Lundberg. J. M.. Hokfelt, T., Anggard, A.. Uvnas-Wallensten. K.. Brimijoin. S. Brodin, E., and Fahrenkrug, J.: Peripheral peptide neurons: Distribution, axonal transport. and some aspects of possible function. In: E. Costa and $\mathrm{M}$. Trabucchi, Eds.: Neural Peptides and Neural Communication. Adv. Biochem. Psychopharm. 22: pp. 25-36 (Raven Press, New York, 1980)

31. Martin W. R. Eades, C. G.. Thompson. J. A.. Huppler, R. F and Gilberg. P. E.: The effects of morphine- and natorphine-like drugs in the nondependent and morphine-dependent chronic spinal dog. J. Pharmacol. Exp. Ther.. 197: 517 (1976).

32. Moss. I. R. and Scarpelli, E. M.: Generation and regulation of breathing in utero: fetal $\mathrm{CO}_{2}$ response test. J. Appl. Physiol., 47: 527 (1979).

33. Pasternak, G. W., Zhang, A., and Tecott, L.: Developmental differences between high and low affinity opiate binding sites: Their relationship to analgesia and respiratory depression. Life Sci., 27: 1185 (1980).

34. Pert, C. B., Kuhar, M. J., and Snyder, S. H.: Autoradiographic localization of the opiate receptor in rat brain. Life Sci., 16: 1849 (1975).

35. Pert, C. B., Kuhar, M. J., and Snyder, S. H.: Opiate Receptor: Autoradiographic localization in rat brain. Proc. Nat. Acad. Sci. 73: 3729 (1976).

36. Schaz, K., Stock, G., Simon, W., Schlor, K., Unger, T., Rockhold, R., and Ganten, D.: Enkephalin effects on blood pressure, heart rate, and baroreceptor reflex. Hypertension, 2: 395 (1980).

37. Schultzberg, M., Hokfelt T., Lundberg, J. M., Terenius, L., Elfuin, L. G., and Elde, R.: Enkephalin-like immunoreactivity in nerve terminals in sympathetic ganglia and adrenal medulla and in adrenal medullary gland cells. Acta Physiol. Scand., 103: 475 (1978).

38. Spiehler, V., Fairhurst, A. S., and Randall, L. O.: The interaction of phenoxybenzamine with mouse brain opiate receptor. Mol. Pharmacol. 14: 587 (1978).

39. Stine, S. M., Yang. H.-Y. T.. and Costa, E.: Release of enkephalin-like immunoreactive material from isolated bovine chromaffin cells. Neuropharmacology, 19: 683 (1980).

40. Terenius, L.: The opioid receptors and their ligands. In: K. Fuxe. T. Hokfelt, and R. Luft. Eds.: Central Regulation of the Endocrine System. p. 137-148 (Plenum Press, New York, NY, 1978).

41. Viveros, O. H., Diliberto, E. J.. Hazum, E., and Chang, K.-J.: Opiate-like materials in the adrenal medulla: Evidence for storage and secretion with catecholamines. Mol. Pharmacol., 16: 1101 (1979).

42. Weiner, $N$.: Drugs that inhibit adrenergic nerves and block adrenergic receptors In: The Pharmacological Basis of Therapeutics, 6th ed.. pp. 178-184 (Macmillan Publishing Co., Inc., New York, NY, 1980).

43. Worley, R. J., Gant, N. F.. Jr.. Everett, R. B., and MacDonald, P. C.: Vascular responsiveness to pressor agents during human pregnancy. J. Reproduc. Med. 23: 115 (1979). 
44. Yang. H.-Y. T.. Hexum, T., and Costa, E.: Opioid peptides in adrenal gland. Life Sci.. 27: $1119(1980)$

45. Zar, J. M.: Biostatistical Analysis. pp. 159-161. (Prentice-Hall, Inc., 1974).

46. Zhang, A. and Pasternak, G. W.: Ontogeny of opioid pharmacology and receptors: high and low affinity site differences. Eur. J. Pharmacol., 73: 29 (1981).

47. The authors appreciate and wish to acknowledge the advice of Dr. Julien I.E. Hoffman and Dr. Michael A. Heymann, the technical assistance of Ms. Christine Roman and the editorial assistance of Ms. Susan Axelrod in preparation of this manuscript.

48. Requests for reprints should be addressed to: Dr. E.F. LaGamma. Assistant

Copyright (C) 1983 International Pediatric Research Foundation, Inc. $0031-3998 / 83 / 1702-0162 \$ 02.00 / 0$
Professor of Pediatrics. The Perinatology Center and Division of Developmental Neurology, The New York Hospital-Cornell Medical Center, New York, New York, 10021.

49. This work was supported in part by a grant from the U.S. Public Health Service. Program Project Grant HL24056, and Public Health Service Award HL0075601. Dr. Itskovitz is an NIH International Fellow (TWO 2767) from Rambam Medical Center, Haifa, Israel.

50. Received for publication August 18, 1981.

51. Accepted for publication June 1, 1982. 